Research Paper

\title{
High seroprevalence of Simkania negevensis in Jordan
}

\author{
Hesham M. Al-Younes ${ }^{1}$, Mika Paldanius ${ }^{2}$ \\ ${ }^{1}$ Department of Biological Sciences, Faculty of Science, University of Jordan, Amman, Jordan. \\ ${ }^{2}$ Northern Finland Laboratory Centre, Nordlab, Oulu, Finland
}

Submitted: October 14, 2013; Approved: June 6, 2014.

\begin{abstract}
The bacterium Simkania negevensis is a germ associated with respiratory diseases. This study aims at estimating the prevalence of Simkania in the Jordanian population. Serum samples from 664 Jordanian males and females, aged 2 to 86 years were collected. IgG and IgM Simkania-specific antibodies were detected using an indirect immunofluorescence test. Seropositivity titers for IgG and IgM were defined as 1:8 and 1:10, respectively. The overall prevalence of IgG antibody in all examined Jordanian nationals was $58.4 \%$. IgG seropositivity was low in children under the age of 10 years (34.2\%), and increased rapidly with age and ranged between $49.4 \%$ and $72 \%$. Simkania-specific IgM was detected in $24.8 \%$ of subjects. IgM prevalence in children under 10 years was lowest $(10.5 \%)$ and increased in older ages and remained above $20 \%$. Overall detection rates of both IgG and IgM were significantly higher in females than males (60.7\% vs. 54.5\% for IgG and $26.7 \% v s .21 .7 \%$ for IgM). These data indicate that Simkania infection is highly prevalent in Jordan. The high level of seropositivity is most likely maintained by re-infections or chronic infections. Our data may serve as a basis to elucidate the pathogenesis of Simkania in Jordan.
\end{abstract}

Key words: Jordan, immunofluorescence, prevalence, Simkania.

\section{Introduction}

Simkania negevensis, formerly called microorganism 'Z' or 'Simkania Z', is a Chlamydia-related bacterium that belongs to the novel family Simkaniaceae within the order Chlamydiales. It was first described in 1993 as a cell culture contaminant of unknown origin (Kahane et al., 1993). This microorganism shares some biological properties with members of the family Chlamydiaceae; for instance, it is an obligate intracellular microorganism and has a typically two-stage developmental cycle, consisting of infectious elementary bodies and replicative reticulate bodies (Kahane et al., 1993). S. negevensis appears to be transmitted via domestic water (Kahane et al., 2007).

Seroepidemiological studies from different parts of the world demonstrated remarkable differences in seropositivity rates that range from as low as $4.3 \%$ to approximately 80\% (Friedman et al., 1999, 2003, 2006; Johnsen et al., 2005; Yamaguchi et al., 2005; Korppi et al., 2006; Donati et al., 2013). In addition, infection with Simkania has been associated with respiratory diseases, such as pneu- monia, exacerbation of chronic obstructive pulmonary disease and bronchiolitis (Lieberman et al., 1997, 2002; Kahane et al., 1998; Greenberg et al., 2003; Friedman et al., 2003, 2006; Kumar et al., 2005; Fasoli et al., 2008; Heiskanen-Kosma et al., 2008; Nascimento-Carvalho et al., 2009). However, Niemi and coworkers (2001) were not able to detect an association of Simkania with respiratory diseases. Importantly, DNA of Simkania has been amplified from an aortic aneurysm (Ossewaarde and Meijer, 1999). In a very recent report, this bacterium has been linked to gastrointestinal infections (Donati et al., 2013).

Simkania organisms can be detected in clinical specimens by cultivation in cell culture, PCR and serology (Friedman et al., 2003, 2006). The microimmunofluorescence test (MIF) was found to be specific for the pathogen (Yamaguchi et al., 2005; Fasoli et al., 2008) and, therefore, is frequently used for the diagnosis of Simkania infections (Korppi et al., 2006; Fasoli et al., 2008; Heiskanen-Kosma et al., 2008; Nascimento-Carvalho et al., 2009; Donati et al., 2013). 
The prevalence of Simkania infection in subjects and the correlation of this pathogen with respiratory infections and other illnesses have not yet been investigated in Jordan. The present study aimed, using MIF, to determine the prevalence of Simkania infection among Jordanian volunteers from both sexes and of different ages.

\section{Materials and Methods}

\section{Study participants and serum collection}

Blood samples were drawn from 664 Jordanian individuals who attended outpatient clinics at the hospital of the University of Jordan, Amman, Jordan, during December, 2008 and May, 2009 for various reasons. Serum samples were separated and stored at $-20^{\circ} \mathrm{C}$ until tested. The study population comprised individuals aged 2 to 86 years (mean age 40.1 years) with 244 males and 420 females (mean age 42.3 and 39 years, respectively). Subjects were divided into eight age groups: $2-9$ years $(n=38), 10-19$ years $(n=62)$, 20-29 years $(\mathrm{n}=143), 30-39$ years $(\mathrm{n}=100), 40-49$ years $(\mathrm{n}=93), 50-59$ years $(\mathrm{n}=83), 60-69$ years $(\mathrm{n}=54)$ and $\geq 70$ years $(n=91)$. Written informed consent was obtained from adult individuals or from parents of children, who participated in the study. The study was approved by the appropriate Committees in the institution and in the Deanship of Academic Research, The University of Jordan.

\section{Simkania antigen preparation}

Elementary bodies of $S$. negevensis (American Type Culture Collection VA, USA; no. VR-1471) were used as antigen in the serologic test. Bacterial growth, purification of elementary bodies and preparation of antigen were performed as previously described (Korppi et al., 2006; Heiskanen-Kosma et al., 2008).

\section{Serologic test}

Detection of IgG and IgM antibodies specific to $S$. negevensis in collected sera was performed using in-house MIF test. Positive and negative control sera were also applied in each run. Diluted sera added onto slides dotted with the antigen were incubated in a humid chamber at $37^{\circ} \mathrm{C}$ for either $1 \mathrm{~h}$ or $3 \mathrm{~h}$ to detect IgG or IgM, respectively. After being washed, antigen spots were overlaid with fluoresceinlabeled goat anti-human IgG or IgM antibody (Bio-Rad, CA, USA) and incubated as before. Slides were then washed, mounted and examined under an epifluorescence microscope (Nikon, Japan) at 400X. The cut-off values for seropositivity were 1:8 for IgG and 1:10 for IgM (Yamaguchi et al., 2005; Heiskanen-Kosma et al., 2008).

\section{Statistical analysis}

The statistical analysis of the data obtained for gender and age groups was determined using chi-square test. A probability value (p) of $<0.05$ was considered statistically significant.

\section{Results}

IgG and IgM seropositivities for Simkania infection in Jordan were evaluated using sera collected from a total of 664 Jordanian nationals (420 females and 244 males). The mean age of female and male participants was 39 and 42.3 years, respectively. Tables 1 and 2 summarize the presence of Simkania IgG and IgM antibodies, respectively, in males and females, grouped into eight age groups. Moreover, Tables 1 and 2 show the percentages of IgG and IgM prevalence within the age groups after combining the genders.

When both genders were combined, the IgG and IgM detection rates were the lowest in participants under the age of 10 years and remained relatively high in older age groups. Peak IgG and IgM seropositivities were detected in

Table 1 - Seroprevalence of anti-S. negevensis IgG antibodies in Jordanian population in relation to age and gender.

\begin{tabular}{|c|c|c|c|c|c|c|c|c|c|}
\hline \multirow[t]{2}{*}{ Age group (years) } & \multicolumn{3}{|c|}{ Males } & \multicolumn{3}{|c|}{ Females } & \multicolumn{3}{|c|}{ Both genders } \\
\hline & $\begin{array}{c}\text { number } \\
\text { examined }\end{array}$ & $\begin{array}{l}\text { No. } \operatorname{IgG}^{\mathrm{a}} \\
\text { positive }\end{array}$ & $\begin{array}{c}\% \text { IgG } \\
\text { positivity }\end{array}$ & $\begin{array}{c}\text { number } \\
\text { examined }\end{array}$ & $\begin{array}{l}\text { No. } \operatorname{IgG}^{\mathrm{a}} \\
\text { positive }\end{array}$ & $\begin{array}{c}\% \text { IgG } \\
\text { positivity }\end{array}$ & $\begin{array}{c}\text { number } \\
\text { examined }\end{array}$ & $\begin{array}{l}\text { No. } \mathrm{IgG}^{\mathrm{a}} \\
\text { positive }\end{array}$ & $\begin{array}{c}\% \text { IgG } \\
\text { positivity }\end{array}$ \\
\hline $2-9 *$ & 28 & 8 & 28.6 & 10 & 5 & 50 & 38 & 13 & 34.2 \\
\hline $10-19$ & 28 & 18 & 64.3 & 34 & 23 & 67.6 & 62 & 41 & 66.1 \\
\hline $20-29 *$ & 33 & 16 & 48.5 & 110 & 60 & 54.5 & 143 & 76 & 53.1 \\
\hline $30-39 *$ & 22 & 14 & 63.6 & 78 & 58 & 74.4 & 100 & 72 & 72 \\
\hline $40-49$ & 25 & 16 & 64 & 68 & 37 & 54.4 & 93 & 53 & 57 \\
\hline $50-59$ & 32 & 13 & 40.6 & 51 & 28 & 54.9 & 83 & 41 & 49.4 \\
\hline $60-69$ & 23 & 16 & 69.6 & 31 & 20 & 64.5 & 54 & 36 & 66.7 \\
\hline$\geq 70^{*}$ & 53 & 32 & 60.4 & 38 & 24 & 63.2 & 91 & 56 & 61.5 \\
\hline
\end{tabular}

${ }^{\mathrm{a}}$ Cut-off value for IgG seropositivity was 1:8.

* Statistically significant difference between males and females $(\mathrm{p}<0.05)$. 
Table 2 - Seroprevalence of IgM antibodies specific to S. negevensis in Jordanian subjects.

\begin{tabular}{|c|c|c|c|c|c|c|c|c|c|}
\hline \multirow[t]{2}{*}{ Age group (years) } & \multicolumn{3}{|c|}{ Males } & \multicolumn{3}{|c|}{ Females } & \multicolumn{3}{|c|}{ Both genders } \\
\hline & $\begin{array}{l}\text { number } \\
\text { examined }\end{array}$ & $\begin{array}{c}\text { No. } \operatorname{IgM}^{\mathrm{a}} \\
\text { positive }\end{array}$ & $\begin{array}{c}\% \text { IgM } \\
\text { positivity }\end{array}$ & $\begin{array}{l}\text { number } \\
\text { examined }\end{array}$ & $\begin{array}{l}{\text { No. } \operatorname{IgM}^{\mathrm{a}}}_{\text {positive }}\end{array}$ & $\begin{array}{c}\% \text { IgM } \\
\text { positivity }\end{array}$ & $\begin{array}{l}\text { number } \\
\text { examined }\end{array}$ & $\begin{array}{c}{\text { No. } \operatorname{IgM}^{\mathrm{a}}}_{\text {positive }}\end{array}$ & $\begin{array}{c}\% \text { IgM } \\
\text { positivity }\end{array}$ \\
\hline $2-9 *$ & 28 & 3 & 10.7 & 10 & 1 & 10 & 38 & 4 & 10.5 \\
\hline $10-19$ & 28 & 4 & 14.3 & 34 & 12 & 35.3 & 62 & 16 & 25.8 \\
\hline $20-29^{*}$ & 33 & 9 & 27.3 & 110 & 28 & 25.5 & 143 & 37 & 25.9 \\
\hline $30-39^{*}$ & 22 & 7 & 31.8 & 78 & 27 & 34.6 & 100 & 34 & 34 \\
\hline $40-49$ & 25 & 5 & 20 & 68 & 18 & 26.5 & 93 & 23 & 24.7 \\
\hline $50-59$ & 32 & 7 & 21.9 & 51 & 11 & 21.6 & 83 & 18 & 21.7 \\
\hline $60-69$ & 23 & 5 & 21.7 & 31 & 8 & 25.8 & 54 & 13 & 24.7 \\
\hline$\geq 70^{*}$ & 53 & 13 & 24.5 & 38 & 7 & 18.4 & 91 & 20 & 22 \\
\hline Total* & 244 & 53 & 21.7 & 420 & 112 & 26.7 & 664 & 165 & 24.8 \\
\hline
\end{tabular}

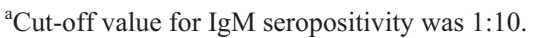

* Statistically significant difference between males and females $(\mathrm{p}<0.05)$.

individuals aged between 30 to 39 years (Tables 1 and 2). The overall seropositivities of $\operatorname{IgG}$ and $\operatorname{IgM}$ antibodies in all subjects tested were $58.4 \%$ and $24.8 \%$, respectively. The detection rates of both antibodies were significantly higher in females compared with males $(\mathrm{p}<0.05)$.

\section{Discussion}

This study confirmed for the first time the presence of S. negevensis in Jordanian population. Serum samples from Jordanian natives from both sexes, aged 2 to 86 years, were utilized to estimate the seroprevalence of $S$. negevensis antibodies using MIF method. The IgG prevalence of Simkania infection was $34.2 \%$ in children aged between 2 and 9 years old and doubled in older children and teenagers aged 10-19 years. In older individuals, the seropositivity remained relatively high and fluctuated between approximately $50 \%$ and $72 \%$. Other population-based studies performed in our geographic area demonstrated results almost comparable to our findings (Friedman et al., 1999, 2003), suggesting that, in the Middle East, S. negevensis infections are very common in children and adult population.

Intriguingly, the overall prevalence of Simkania $\operatorname{IgG}$ and IgM was significantly higher in females than in males, suggesting a possible relationship between gender and the prevalence of bacterial infection. This finding is fully inconsistent with those reported for the prevalence of Simkania-related C. pneumoniae, which was higher in males than in females in many countries including Jordan (Al-Younes, 2014). The higher prevalence rate among females observed here might be due to the relatively low numbers of males investigated compared with female numbers. Therefore, the gender-associated differences in the seropositivity of $S$. negevensis remain inconclusive and deserve to be validated by prospective studies.

The prevalence of Simkania in apparently healthy individuals and possible association of this bacterium with various clinical manifestations, such as respiratory and gastrointestinal diseases, have been investigated in a limited number of countries in North America, Western Europe, the Middle East and East Asia (Yamaguchi et al., 2005; Korppi et al., 2006; Donati et al., 2013). Most epidemiological studies on healthy teenagers and adults detected relatively high seropositivity rates, ranging from $35-68 \%$ in Western Europe, $39-68 \%$ in North America and $55-80 \%$ in the Middle East (Lieberman et al., 1997; Friedman et al., 1999, 2003, 2006; Johnsen et al., 2005; Kumar et al., 2005). In Japan, by contrast, broader seroprevalence analysis, including that in healthy children, youths and older persons, estimated an overall rate of only $4.3 \%$ (Yamaguchi et al., 2005). In this study, the exposure rate to Simkania was analyzed in Jordanian natives from both sexes and of different ages. The overall prevalence of Simkania IgG antibodies was high in the Jordanian population $(\sim 58 \%)$ and comparable to those estimates recorded previously in the Middle East (Friedman et al., 1999, 2003). Differences in global seropositivity rates may be partially due to variations in geographic regions and ethnic groups (Ossewaarde and Meijer, 1999). In our geographic area (the Middle East), infection with Simkania seems to be relatively common as observed here and by others (Friedman et al., 2003).

In the first studies on the prevalence of $S$. negevensis, antibodies to this bacterium were measured by an enzymelinked immunosorbent assay (ELISA), developed to detect IgA and IgG antibodies (Lieberman et al., 1997; Kahane et al., 1998; Friedman et al., 2003). Serologic studies using ELISA test in countries in North America, West Europe and the Middle East indicated antibody rates of IgG in healthy population that ranged from 39 to $80 \%$, suggesting apparently high seroprevalences of Simkania infection. By contrast, a recently developed immunofluorescence-based method (MIF) detected relatively very low overall $\operatorname{IgG}$ seropositivity (4.3\%) against Simkania in healthy Japanese children and adults (Yamaguchi et al., 2005). These contra- 
dictory epidemiological findings obtained using ELISA and MIF raised questions about the clinical significance of antibody reactivity against Simkania, especially when using ELISA (Corsaro et al., 2006). Utilizing MIF, it was subsequently shown that there was a 20 to $30 \%$ seropositivity in Italian children (Fasoli et al., 2008) - a rate higher than that observed by Yamaguchi et al. in Japan (Yamaguchi et al., 2005), but, interestingly, consistent with the high prevalence observed in this study in children aged 2-9 years. Our MIF-based results and those reported by Fasoli and coworkers (2008) are in accordance with those obtained by ELISA in North America, West Europe and Middle East, indicating the feasibility of both tests for diagnosing cases of Simkania infections.

This study shows for the first time the prevalence of $S$. negevensis infection in Jordanian children and adults among both sexes. The first exposure to Simkania begins at a very early age, with most primary infections occurring within the first two decades of life. The stable high detection rates of Simkania $\operatorname{IgG}$ antibodies in subjects older than 20 years may be the result of past infection or frequent reinfection. Our data show that the seroprevalence in the Jordanian population is one of the highest worldwide, when compared to estimates in other populations. Further studies are recommended to link this Chlamydia-like pathogen with pulmonary and non-pulmonary diseases in Jordan.

\section{Acknowledgments}

We thank Miss Heba Jarrar for her skillful technical assistance. We also thank Robin Al-Zar'e for performing statistical analyses. The work was funded by a grant from the Deanship of Academic Research, The University of Jordan, Amman, Jordan.

\section{Declaration of Interest}

This work was financially supported by a grant from the Deanship of the Academic Research, The University of Jordan, Amman, Jordan. There is no commercial relationship or potential conflict of interest related to this paper.

\section{References}

Al-Younes HM (2014) High prevalence of Chlamydia pneumoniae infection in an asymptomatic Jordanian population. J Microbiol Immunol Infect 47:412-417.

Corsaro D, Greub G (2006) Pathogenic potential of novel chlamydiae and diagnostic approaches to infections due to these obligate intracellular bacteria. Clin Microbiol Rev 19:283-297.

Donati M, Fiani N, Di Francesco A, Di Paolo M, Vici M, Cevenini R (2013) IgG and IgA response to Simkania negevensis in sera of patients with respiratory and gastrointestinal symptoms. New Microbiol 36:303-306.

Fasoli L, Paldanius M, Don M, Valent F, Vetrugno L, Korppi M, et al. (2008) Simkania negevensis in community-acquired pneumonia in Italian children. Scand J Infect Dis 40:269272.

Friedman MG, Dvoskin B, Kahane S (2003) Infections with the Chlamydia-like microorganism Simkania negevensis, a possible emerging pathogen. Microbes Infect 5:1013-1021.

Friedman MG, Galil A, Greenberg S, Kahane S (1999) Seroprevalence of IgG antibodies to the Chlamydia-like microorganism 'Simkania Z' by ELISA. Epidemiol Infect 122:117123.

Friedman MG, Kahane S, Dvoskin B, Hartley JW (2006) Detection of Simkania negevensis by culture, PCR, and serology in respiratory tract infection in Cornwall, UK. J Clin Pathol 59:331-333.

Greenberg D, Banerji A, Friedman MG, Chiu CH, Kahane S (2003) High rate of Simkania negevensis among Canadian infants hospitalized with lower respiratory tract infections. Scand J Infect Dis 35:506-508.

Heiskanen-Kosma T, Paldanius M, Korppi M (2008) Simkania negevensis may be a true cause of community acquired pneumonia in children. Scand J Infect Dis 40:127-130.

Johnsen S, Birkebaek N, Andersen PL, Emil C, Jensen JS, Østergaard L (2005) Indirect immunofluorescence and real time PCR for detection of Simkania negevensis infection in Danish adults with persistent cough and in healthy controls. Scand J Infect Dis 37:251-255.

Kahane S, Greenberg D, Friedman MG, Haikin H, Dagan R (1998) High prevalence of "Simkania Z," a novel Chlamydia-like bacterium, in infants with acute bronchiolitis. J Infect Dis 177:1425-1429.

Kahane S, Greenberg D, Newman N, Dvoskin B, Friedman MG (2007) Domestic water supplies as a possible source of infection with Simkania. J Infect 54:75-81.

Kahane S, Gonen R, Sayada C, Elion J, Friedman MG (1993) Description and partial characterization of a new Chlamydialike microorganism. FEMS Microbiol Lett 109:329-333.

Korppi M, Paldanius M, Hyvärinen A, Nevalainen A (2006) Simkania negevensis and newly diagnosed asthma: a casecontrol study in 1- to 6-year-old children. Respirology 11:80-83.

Kumar S, Kohlhoff SA, Gelling M, Roblin PM, Kutlin A, Kahane $\mathrm{S}$, et al. (2005) Infection with Simkania negevensis in Brooklyn, New York. Pediatr Infect Dis J 24:989-992.

Lamoth F, Greub G (2010) Fastidious intracellular bacteria as causal agents of community-acquired pneumonia. Expert Rev Anti Infect Ther 8:775-790.

Lieberman D, Dvoskin B, Lieberman DV, Kahane S, Friedman MG (2002) Serological evidence of acute infection with the Chlamydia-like microorganism Simkania negevensis (Z) in acute exacerbation of chronic obstructive pulmonary disease. Eur J Clin Microbiol Infect Dis 21:307-309.

Lieberman D, Kahane S, Lieberman D, Friedman MG (1997) Pneumonia with serological evidence of acute infection with the Chlamydia-like microorganism "Z". Am J Respir Crit Care Med 156:578-582.

Nascimento-Carvalho CM, Cardoso MR, Paldanius M, Barral A, Araújo-Neto CA, Saukkoriipi A, et al. (2009) Simkania negevensis infection among Brazilian children hospitalized with community-acquired pneumonia. J Infect 58:250-253.

Niemi S, Greub G, Puolakkainen M (2001) Chlamydia-related bacteria in respiratory samples in Finland. Microbes Infect 13:824-827. 
Ossewaarde JM, Meijer A (1999) Molecular evidence for the existence of additional members of the order Chlamydiales. Microbiology 145:411-417.

Yamaguchi T, Yamazaki T, Inoue M, Mashida C, Kawagoe K, Ogawa M, et al. (2005) Prevalence of antibodies against
Simkania negevensis in a healthy Japanese population determined by the microimmunofluorescence test. FEMS Immunol Med Microbiol 43:21-27.

All the content of the journal, except where otherwise noted, is licensed under a Creative Commons License CC BY-NC. 